\title{
Evidence for Different Signaling Pathways Activated by Inducers of Acquired Resistance in Wheat
}

\author{
Ulrich Schaffrath, Ernst Freydl, and Robert Dudler \\ Institute for Plant Biology, University of Zürich, Zollikerstr. 107, CH-8008 Zürich, Switzerland \\ Received 17 February 1997. Accepted 9 May 1997.
}

\begin{abstract}
Acquired resistance (AR) of wheat (Triticum aestivum) to the powdery mildew fungus Erysiphe graminis f. sp. tritici can be induced either by inoculation with the nonhost pathogen $E$. graminis f. sp. hordei or by treatment with chemical substances such as benzo(1,2,3)thiodiazole-7carbothioic acid $S$-methyl ester (BTH). In the dicotyledonous plants tobacco and Arabidopsis, induction of AR by pathogens and BTH is accompanied by the expression of a characteristic set of genes. Here we report that in wheat, BTH treatment failed to activate genes whose transcripts accumulate after AR induction by nonhost pathogens, whereas BTH-inducible genes were not activated by an appropriate pathogen inoculation. This suggests that at least two different pathways exist for the induction of $A R$ in monocots.
\end{abstract}

Acquired resistance (AR) is an inducible defense mechanism exhibited by many plants that provides protection against a broad range of pathogens. AR, which was first observed by Chester (1933) and later described by Ross (1961), can be induced by incompatible pathogens, by pathogen-derived elicitors (Schaffrath et al. 1995; Keller et al. 1996), and by certain chemicals, including salicylic acid (SA) (White 1979), 2,6-dichloroisonicotinic acid (INA) (Métraux et al. 1991), and benzo(1,2,3)thiodiazole-7-carbothioic acid $S$-methyl ester (BTH) (Görlach et al. 1996). After induction, protection against a later infection can be restricted to the leaf treated with an inducer (local acquired resistance, LAR) or can encompass tissue of the plant that has not been treated (systemic acquired resistance, SAR) (Ross 1961). SAR has been most extensively characterized in cucumber (Kuć et al. 1975; Kuć and Richmond 1977), tobacco (Kuć 1982; Vernooij et al. 1995), and more recently in Arabidopsis (Mauch-Mani and Slusarenko 1994; Lawton et al. 1995). Related sets of gene families (SAR genes) have been characterized in tobacco (Ward et al. 1991) and Arabidopsis (Uknes et al. 1992) that are coordinately activated during the SAR response. These genes encode pathogenesis-related (PR) proteins and are likely to play an important role during the onset and maintenance of SAR, since constitutive expression of such genes in transgenic plants can enhance disease resistance (Broglie et al.

Corresponding author: R. Dudler; Telephone: +41 138542 52;

Fax: +41 138542 04; E-mail: rdudler@botinst.unizh.ch
1991; Alexander et al. 1993; Liu et al. 1994; Logemann et al. 1994; Jach et al. 1995).

In both Arabidopsis and tobacco, the same set of SAR genes and the same spectrum of resistance specificities were activated by the chemical inducers SA, INA, and BTH and the biological inducing agents (Ward et al. 1991; Uknes et al. 1992, 1993; Vernooij et al. 1995; Lawton et al. 1995, 1996; Friedrich et al. 1996). SA appears to be an important component of the signal transduction pathway leading to SAR. Not only can SA induce SAR when applied exogenously, but it was shown to accumulate during the onset of SAR in cucumber (Métraux et al. 1990), tobacco (Malamy et al. 1990), and Arabidopsis (Uknes et al. 1993). Furthermore, genetically engineered tobacco and Arabidopsis plants unable to accumulate SA failed to exhibit SAR after induction with pathogens (Gaffney et al. 1993; Vernooij et al. 1994). However, application of INA and BTH still induced SAR and SAR gene activity in such plants (Delaney et al. 1994; Vernooij et al. 1994; Friedrich et al. 1996; Lawton et al. 1996). This, together with the fact that SAR induction by SA, INA, and BTH is blocked in the SAR-defective Arabidopsis mutant niml, indicates that these chemicals act through a common SAR signal transduction pathway (Delaney et al. 1995; Lawton et al. 1996).

$\mathrm{AR}$ in monocots is less well studied. After induction with biological agents, LAR has been demonstrated in barley (Ouchi et al. 1974), rice (Horino 1976), and wheat (Schweizer et al. 1989). SAR was reported in rice after preinoculation with Pseudomonas syringae pv. syringae (Smith and Métraux 1991). As in dicotyledonous plants, AR can also be triggered by application of chemicals, e.g., by probenazole in rice (Watanabe et al. 1979), by INA in barley (Kogel et al. 1994), and by SA, INA, and BTH in wheat (Görlach et al. 1996).

LAR in wheat against powdery mildew induced by inoculation with the nonhost pathogen Erysiphe graminis f. sp. hordei (which causes powdery mildew of barley) is accompanied by the accumulation of mRNA species, including the ones represented by the WIR (for wheat induced resistance) cDNA clones (Schweizer et al. 1989; Kmecl et al. 1995). WIR1 and its homolog WIR4 encode a putative cell wall protein (Bull et al. 1992); WIR2, a thaumatinlike protein (Rebmann et al. 1991b); and WIR3, a peroxidase (Rebmann et al. 1991a). Similarly, a set of transcripts that accumulate after chemical resistance induction have been cloned as cDNAs (cWCI clones, for wheat chemical induction) (Görlach et al. 1996). cWCI-2 encodes a lipoxygenase; cWCI-4 encodes a 
cysteine proteinase; and cWCI-1, cWCI-3, and cWCI-5 encode proteins of no known function (Görlach et al. 1996). On the basis of their primary sequences, the sets of available WIR and cWCI clones do not overlap.

We wanted to determine whether the accumulation of WIR and WCI transcripts can be induced by both biotic and chemical resistance activators, i.e., whether the corresponding genes exhibit an expression pattern analogous to the $S A R$ genes of tobacco and Arabidopsis. To this end, 14-day-old wheat plants (Triticum aestivum cv. Kanzler) grown under a 16-h photoperiod were either inoculated with E. graminis f. sp. hordei spores or sprayed with a $1 \mathrm{mM}$ BTH solution as described by Kmecl et al. (1995) and Görlach et al. (1996), respectively. RNA was extracted at various time points after the treatments and subjected to gel blot analysis according to standard procedures (Maniatis et al. 1982) with WIR and WCI cDNAs as probes. The results are depicted in Figure 1. As expected, inoculation with the nonhost pathogen E. graminis f. sp. hordei resulted in the transient accumulation of WIR transcripts (Fig. 1A). In contrast, E. graminis f. sp. hordei inoculation had no effect on cWCI transcript levels (Fig. 1B). Similarly, cWCI-specific transcripts accumulated after BTH treatment (Fig. 2A), as was reported by Görlach et al. (1996). However, WIR transcript levels were identical in BTH- and mock-treated plants (Fig. 2B). These results show that BTH is not capable of inducing genes typically activated in biologically induced wheat plants and that WCI genes are not inducible by a treatment with a biological inducer. Additional experiments with SA and INA yielded results identical to the ones obtained with BTH (data not shown). WCI transcript accumulation was reported to occur 9 to 12 days after infec- tion of wheat with a compatible race of wheat powdery mildew (Görlach et al. 1996). However, by that time, infected leaves are already heavily overgrown by the fungus, and thus this late accumulation may be a secondary effect rather than a direct result of the host-parasite interaction.

The fact that in wheat the biological and chemical AR inducers result in the accumulation of nonidentical sets of transcripts indicates the existence of different signal transduction pathways. SA, INA, and BTH interfere with one of these, while the other one is independent of these chemicals but is activated by the biological inducer E. graminis f. sp. hordei. Equivalent pathways may also exist in rice. AR in rice induced by P. syringae pv. syringae (Smith and Métraux 1991) results in the accumulation of transcripts homologous to the wheat WIR1, WIR2, and WIR3 cDNA clones PIR1 (unpublished results), PIR2 (Reimmann and Dudler 1993), and PIR3 (Reimmann et al. 1992). BTH has been reported to be a potent inducer of AR in rice as well (Görlach et al. 1996). However, BTH does not lead to the accumulation of PIR transcripts in rice (unpublished results). Since clones representing chemically induced rice transcripts were not available and we were unable to detect transcript accumulation in BTH-treated or $P$. syringae pv. syringae-inoculated rice plants with the heterologous WCI cDNAs as probes, the reciprocal experiment could not be performed.

Evidence for different pathways leading to defense responses has recently also been reported for Arabidopsis and tobacco. Whereas classical SAR in these plants requires the SA signaling pathway, systemic resistance induced in Arabidopsis by certain root-colonizing bacteria was reported to be independent of SA accumulation and SAR gene expression
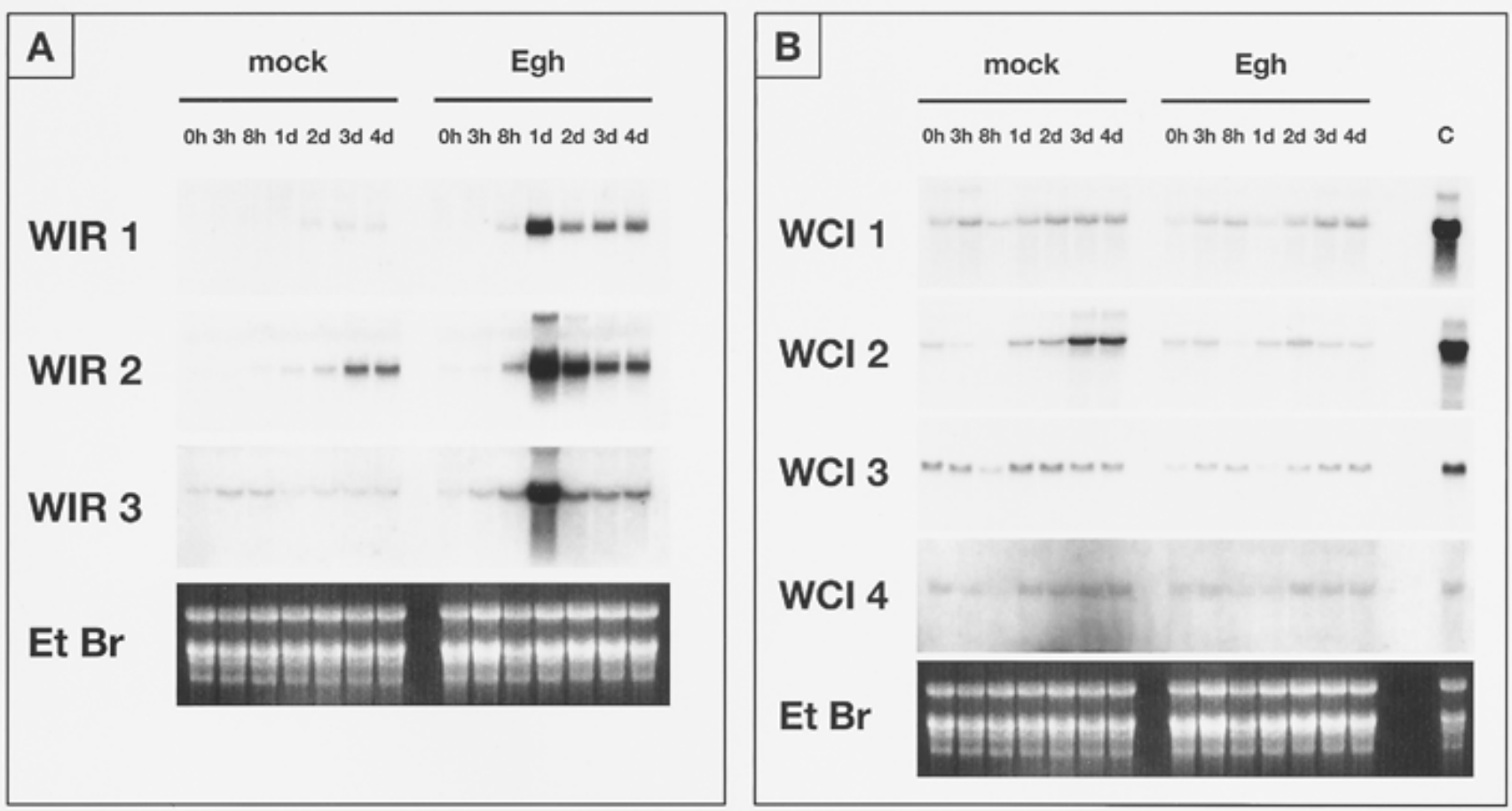

Fig. 1. Time course of mRNA accumulation in wheat in response to Erysiphe graminis f. sp. hordei (Egh) inoculation or mock treatment. Total RNA was extracted at the time points indicated and subjected to gel blot analysis. Identical blots containing $10 \mu \mathrm{g}$ of RNA per lane were hybridized to radiolabeled inserts of WIR (A) and WCI (B) cDNAs. The autoradiograms of RNA blots and one representative corresponding gel stained with ethidium bromide (Et Br) are shown. The lane in $\mathbf{B}$ labeled $\mathrm{C}$ contained control RNA extracted from BTH-treated plants 3 days after spraying. 
(Pieterse et al. 1996). The pathogen-induced systemic activation of a defensin gene in Arabidopsis has also been found to be SA independent (Penninckx et al 1996). Furthermore, Malamy et al. (1996) reported evidence for the occurrence of an SA-independent pathway leading to resistance to tobacco mosaic tobamovirus and expression of a $S A R$ gene in tobacco.

Our results demonstrate that WIR and WCI genes are activated by different signaling pathways. Thus, the behavior of these genes is different from that of the $S A R$ genes characterized in the dicotyledonous species tobacco and Arabidopsis. It has been postulated that a chemical inducer of true SAR should elicit the same responses as biological inducers (Kessmann et al. 1994). Because a biological model of SAR in wheat has not been described, it is not clear at present whether BTH induces SAR in wheat, and presently none of the WIR and $W C I$ genes qualifies as a $S A R$ gene as defined in dicot model systems.

One of the two different pathways is activated by inoculation with E. graminis f. sp. hordei and the other by foliar application of BTH, and both treatments lead to the establishment of a physiological state of increased disease resistance. It is not known at present how the underlying mechanisms of disease resistance are related in the two cases. Extreme possi- bilities are that they are identical, i.e., that common molecular processes causing AR are activated, or that they are unconnected and different molecular events underlying phenotypically similar AR phenomena are activated. If the former were the case, one would have to conclude that the activation of the genes corresponding to the WIR and WCI cDNA clones is not causally connected to the establishment of the resistant state. In contrast, a causal function would be compatible, although by no means proved, with the latter possibility. Of course, intermediate situations between the two extremes are also possible. One could speculate that biological and chemical inducers activate overlapping sets of genes and that the products of specific subsets of these genes are causing increased resistance toward specific pathogens. Experiments with transgenic plants that exhibit altered expression characteristics of such genes may help to determine their function.

\section{ACKNOWLEDGMENTS}

We thank P. Schweizer for the WIR cDNA clones and J. Görlach for the WCI cDNAs. This work was supported by the Kommission zur Förderung der wissenschaftlichen Forschung (KWF) and Ciba-Geigy AG, Basel, Switzerland.

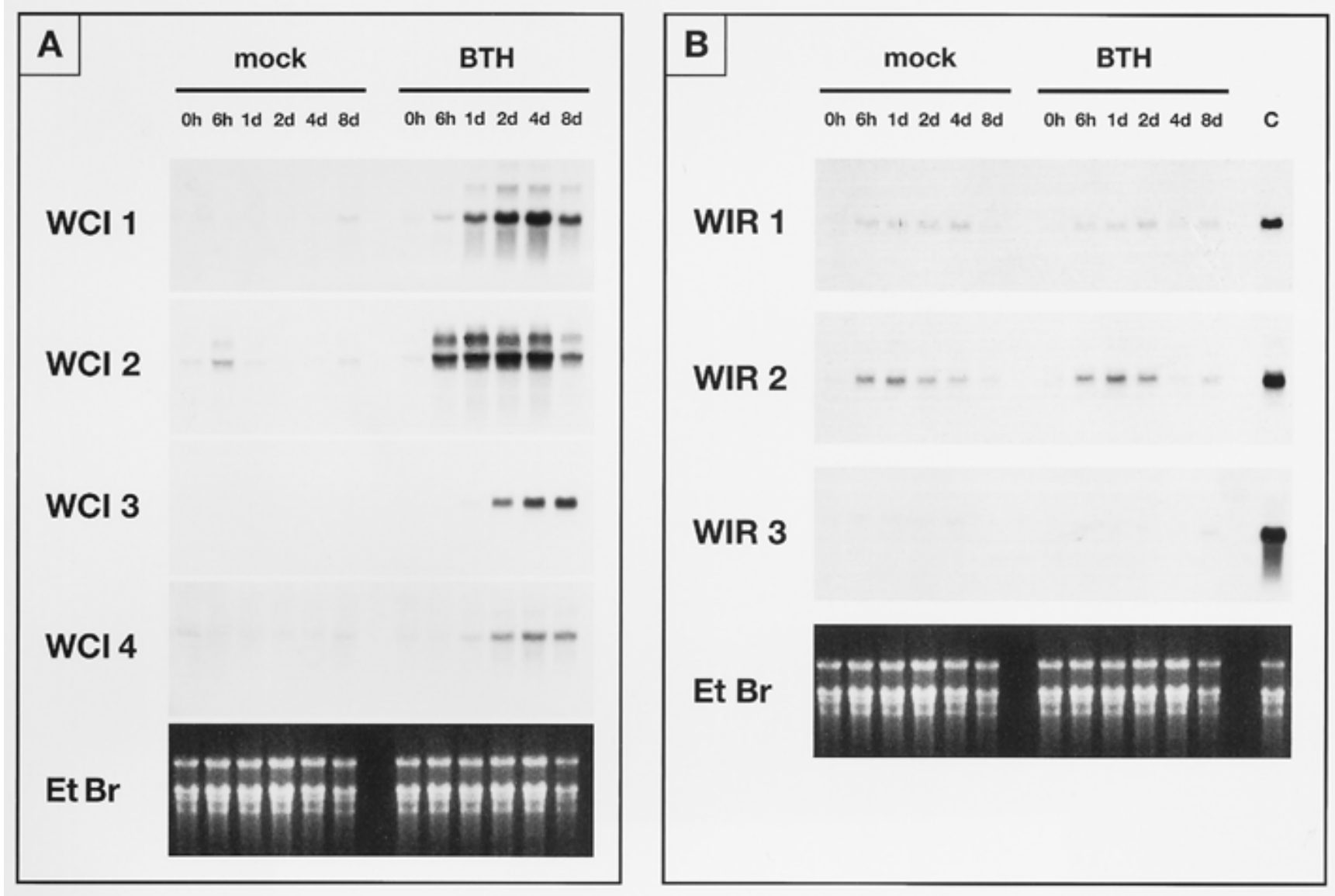

Fig. 2. Time course of mRNA accumulation in response to BTH treatment. Wheat seedlings were sprayed with a $1 \mathrm{mM}$ suspension of BTH in distilled water, and mock-treated plants were sprayed with distilled water. Total RNA was extracted at different time points and loaded on gels (10 $\mu \mathrm{g}$ per lane). Identical blots were probed with radiolabeled inserts of WCI (A) and WIR (B) cDNAs. Loading of equal amounts of RNA was confirmed by ethidium bromide (Et Br) staining. A representative gel is shown. The lane in B labeled C contained RNA extracted from plants $24 \mathrm{~h}$ after inoculation with Erysiphe graminis f. sp. hordei. 


\section{LITERATURE CITED}

Alexander, D., Goodman, R. M., Gut-Rella, M., Glascock, C., Weymann, K., Friedrich, L., Maddox, D., Ahl Goy, P., Luntz, T., Ward, E., and Ryals, J. 1993. Increased tolerance to two oomycete pathogens in transgenic tobacco expressing pathogenesis-related protein 1a. Proc. Natl. Acad. Sci. USA 90:7327-7331.

Broglie, K., Chet, I., Holliday, M., Cressman, R., Biddle, P., Knowlton, S., Mauvais, J. C., and Broglie, R. 1991. Transgenic plants with enhanced resistance to the fungal pathogen Rhizoctonia solani. Science 254:1194-1197.

Bull, J., Mauch, F., Hertig, C., Rebmann, G., and Dudler, R. 1992. Sequence and expression of a wheat gene that encodes a novel protein associated with pathogen defense. Mol. Plant-Microbe Interact. 5:516519.

Chester, K. S. 1933. The problem of acquired physiological immunity in plants. Q. Rev. Biol. 8:275-324.

Delaney, T. P., Uknes, S., Vernooij, B., Friedrich, L., Weymann, K. Negrotto D., Gaffney, T., Gut-Rella, M., Kessmann, H., Ward, E., and Ryals, J. 1994. A central role of salicylic acid in plant disease resistance. Science 266:1247-1250.

Delaney, T. P., Friedrich, L., and Ryals, J. A. 1995. Arabidopsis signal transduction mutant defective in chemically and biologically induced disease resistance. Proc. Natl. Acad. Sci. USA 92:6602-6606.

Friedrich, L., Lawton, K., Ruess, W., Masner, P., Specker, N., Gut Rella, M., Meier, B., Dincher, S., Staub, T., Uknes, S., Métraux, J.-P., Kessmann, H., and Ryals, J. 1996. A benzothiadiazole derivative induces systemic acquired resistance in tobacco. Plant J. 10:61-70.

Gaffney, T., Friedrich, L., Vernooij, B., Negrotto D., Nye, G., Uknes, S., Ward, E., Kessmann, H., and Ryals, J. 1993. Requirement for salicylic acid for the induction of systemic acquired resistance. Science 261: 754-756.

Görlach, J., Volrath, S., Knauf-Beiter, G., Hengy, G., Beckhove, U., Kogel, K.-H., Oosterdorp, M., Staub, T., Ward, E., Kessmann, H., and Ryals, J. 1996. Benzothiadiazole, a novel class of inducers of systemic acquired resistance, activates gene expression and disease resistance in wheat. Plant Cell 8:629-643.

Horino, O. 1976. Induction of bacterial leaf blight resistance by incompatible strains of Xanthomonas oryzae in rice. Pages 43-55 in: Biochemistry and Cytology of Plant Parasite Interactions. K. Tomiyama, J. Daly, I. Uritani, H. Oku, and S. Ouchi, eds. Kodanska, Tokyo.

Jach, G., Görnhard, B., Mundy, J., Logeman, J., Pinsdorf, E., Leah, R., Schell, J., and Maas, C. 1995. Enhanced quantitative resistance against fungal disease by combinatorial expression of different barley antifungal proteins in transgenic tobacco. Plant J. 8:97-109.

Keller, H., Blein, J.-P., Bonnet, P., and Ricci, P. 1996. Physiological and molecular characteristics of elicitin-induced systemic acquired resistance in tobacco. Plant Physiol. 110:365-376.

Kessmann, H., Staub, T., Hofmann, C., Maetzke, T., Herzog, J., Ward, E., Uknes, S., and Ryals J. 1994. Induction of systemic acquired disease resistance in plants by chemicals. Annu. Rev. Phytopathol. 32:439-459.

Kmecl, A., Mauch, F., Winzeler, M., and Dudler, R. 1995. Quantitative field resistance of wheat to powdery mildew and defense reactions at the seedling stage: Identification of potential markers. Physiol. Mol. Plant Pathol. 47:185-199.

Kogel, K.-H., Beckhove, U., Dreschers, J., Münch, S., and Romme, Y. 1994. Acquired resistance in barley. Plant Physiol. 106:1269-1277.

Kuć, J. 1982. Induced immunity to plant disease. BioScience 32:854860.

Kuć, J., and Richmond, S. 1977. Aspects of the protection of cucumber against Colletotrichum lagenarium by Colletotrichum lagenarium. Phytopathology 67:533-536.

Kuć, J., Shockley, G., and Kearney, K. 1975. Protection of cucumber against Colletotrichum lagenarium by Colletotrichum lagenarium. Physiol. Plant Pathol. 7:195-199.

Lawton, K., Weymann, K., Friedrich, L., Vernooij, B., Uknes, S., and Ryals, J. 1995. Systemic acquired resistance in Arabidopsis requires salicylic acid but not ethylene. Mol. Plant-Microbe Interact. 8:863870.

Lawton, K., Friedrich, L., Hunt, M., Weymann, K., Delaney, T., Kessmann, H., Staub, T., and Ryals, J. 1996. Benzothiadiazole induces disease resistance in Arabidopsis by activation of the systemic resistance signal transduction pathway. Plant J. 10:71-82.
Liu, D., Raghothama, K. M., Hasegawa, P. M., and Bressan, R. A. 1994. Osmotin overexpression in potato delays development of disease symptoms. Proc. Natl. Acad. Sci. USA 91:1888-1892.

Logeman, J., Melchers, L. S., Tigelaar, H., Sela-Buurlage, M. B., Ponstein, A. S., van Roekel, J. S. C., Bres-Vloemans, S. A., Dekker, I., Cornelissen, B. J. C., van den Elzen, P. J. M., and Jongedijk, E. 1994. Synergistic activity of chitinase and $\beta$-1,3-glucanase enhances Fusarium resistance in transgenic tomato plants. J. Cell Biochem. 18A:88.

Malamy, J., Carr, J. P., Klessig, D. F., and Raskin, I. 1990. Salicylic acid: A likely endogenous signal in the resistance response of tobacco to viral infection. Science 250:1002-1004.

Malamy, J., Sánchez-Casas, P., Hennig, J., Guo, A., and Klessig, D. F. 1996. Dissection of the salicylic acid signaling pathway in tobacco. Mol. Plant-Microbe Interact. 9:474-482.

Maniatis, T., Fritsch, E. F., and Sambrook, J. 1982. Molecular Cloning A Laboratory Manual. Cold Spring Harbor Laboratory, Cold Spring Harbor, NY.

Mauch-Mani, B., and Slusarenko, A. J. 1994. Systemic acquired resistance in Arabidopsis thaliana induced by a predisposing infection with a pathogenic isolate of Fusarium oxysporum. Mol. PlantMicrobe Interact. 7:378-383.

Métraux, J.-P., Signer, H., Ryals, J., Ward, E., Wyss-Benz, M., Gaudin, J., Rascdorf, K., Schmid, E., Blum, W., and Inverardi, B. 1990. Increase in salicylic acid at the onset of systemic acquired resistance in cucumber. Science 250:1004-1006.

Métraux, J.-P., Ahl Goy, P., Staub, T., Speich, J., Steinemann, A., Ryals, J., and Ward, E. 1991. Induced systemic resistance in cucumber in response to 2,6-dichloro-isonicotinic acid and pathogens. Pages 432 439 in: Advances in Molecular Genetics of Plant-Microbe Interactions, vol. 1. H. Hennecke and D. P. S. Verma, eds. Kluwer, Dordrecht, the Netherlands.

Ouchi, S., Oku, H., Hibino, C., and Aldyama, I. 1974. Induction of accessibility and resistance in leaves of barley by some races of Erysiphe graminis. Phytopathol. Z. 79:24-34.

Penninckx, I., Eggermont, K., Terras, F. R. G., Thomma, B., Desamblanx, G. W., Buchala, A., Métraux, J. P., Manners, J. M., and Broekaert, W. F. 1996. Pathogen-induced systemic activation of a plant defensin gene in Arabidopsis follows a salicylic acid-independent pathway. Plant Cell 8:2309-2323.

Pieterse, C., van Wees, S., Hoffland, E., van Pelt, J., and van Loon, L. 1996. Systemic resistance in Arabidopsis induced by biocontrol bacteria is independent of salicylic acid accumulation and pathogenesis-related gene expression. Plant Cell 8:1225-1237.

Rebmann, G., Hertig, C., Bull, J., Mauch, F., and Dudler. R. 1991a Cloning and sequencing of cDNAs encoding a pathogen-induced putative peroxidase of wheat. Plant Mol. Biol. 16:329-331.

Rebmann, G., Mauch, F., and Dudler, R. 1991b. Sequence of a whea cDNA encoding a pathogen-induced thaumatin-like protein. Plant Mol. Biol. 17:283-285.

Reimmann, C., and Dudler, R. 1993. cDNA cloning and sequence analysis of a pathogen-induced thaumatin-like protein from rice (Oryza sativa). Plant Physiol. 101:1113-1114.

Reimmann, C., Ringli, C., and Dudler, R. 1992. Complementary DNA cloning and sequence analysis of a pathogen-induced putative peroxidase from rice. Plant Physiol. 100:1611-1612.

Ross, F. A. 1961. Systemic acquired resistance induced by localized virus infection in plants. Virology 14:340-358.

Schaffrath, U., Scheinpflug, H., and Reisener, H. J. 1995. An elicitor from Pyricularia oryzae induces resistance responses in rice: Isolation, characterization and physiological properties. Physiol. Mol. Plant Pathol. 46:293-307.

Schweizer, P., Hunziker, W., and Mösinger, E. 1989. cDNA cloning, in vitro transcription and partial sequence analysis of mRNA from winter wheat with induced resistance to Erysiphe graminis f. sp. tritici. Plant Mol. Biol. 12:643-654.

Smith, J. A., and Métraux, J.-P. 1991. Pseudomonas syringae pv. syringae induces systemic resistance to Pyricularia oryzae in rice. Physiol. Mol. Plant Pathol. 39:451-461.

Uknes, S., Mauch-Mani, B., Moyer, M., Potter, S., Williams, S., Dincher, S., Chandler, D., Slusarenko, A., Ward, E., and Ryals, J. 1992. Acquired resistance in Arabidopsis. Plant Cell 4:645-656.

Uknes, S., Winter, A. M., Delaney, T., Vernooij, B., Morse, A., Friedrich, L., Nye, G., Potter, S., Ward, E., and Ryals, J. 1993. Biological induction 
of systemic acquired resistance in Arabidopsis. Mol. Plant-Microbe Interact. 6:692-698

Vernooij, B., Friedrich, L., Morse, A., Reist, R., Kolditz-Jawhar, R., Ward, E., Uknes, S., Kessmann, H., and Ryals, J. 1994. Salicylic acid is not the translocated signal responsible for inducing acquired resistance but is required in signal transduction. Plant Cell 6:959-965.

Vernooij, B., Friedrich, L., Ahl Goy, P., Staub, T., Kessmann, H., and Ryals, J. 1995. 2,6-Dichloroisonicotinic acid-induced resistance to pathogens without the accumulation of salicylic acid. Mol. PlantMicrobe Interact. 8:228-234.
Ward, E. R., Uknes, S. J., Williams, S. C., Dincher, S. S., Wiederhold, D. C., Alexander, D. C., Ahl-Goy, P., Métraux, J.-P., and Ryals, J. A 1991. Coordinate gene activity in response to agents that induce systemic acquired resistance. Plant Cell 3:1085-1094.

Watanabe, T., Sekizawa, Y., Shimura, H., Suzuki, Y., Matsumoto, M., Iwata, M., and Mase, S. 1979. Effects of Probenazole (Oryzemate) on rice plants with reference to controlling rice blast. J. Pestic. Sci. 4:5359.

White, R. F. 1979. Acetylsalicylic acid (aspirin) induces resistance to tobacco mosaic virus in tobacco. Virology 99:410-412. 